Article

\title{
Motivation of male adolescents to become perpetrators of violence: A study of phenomenology
}

\author{
Munqidz Zahrawaani, ${ }^{1,2}$ Nani Nurhaeni, ${ }^{3}$ Allenidekania ${ }^{3}$ \\ ${ }^{1}$ Faculty of Nursing, Universitas Indonesia, Depok, West Java; ${ }^{2}$ Poltekkes Kemenkes Palangkaraya, Palangka \\ Raya, Kalimantan Tengah; ${ }^{3}$ Department of Pediatric Nursing, Faculty of Nursing, Universitas Indonesia, Depok, \\ West Java, Indonesia
}

\begin{abstract}
Background: Violence committed by adolescents is a serious public health problem. More than ten percent of youth violence have been subjected to violence and more than fifty percent attacks and serious violence.

Design and Methods: A qualitative study with a phenomenological study design in which semi-structured interviews were conducted with participants who were once challenged by violence and are now kept in LPKA Class II Jakarta.

Results: This qualitative study explores adolescent motivation to become violent perpetrators. This study discusses four major themes, namely, i) Unsafe environmental conditions; ii) Unpleasant past experiences; iii) Childhood trauma; and iv) Peer group solidarity or friendship.

Conclusions: Adolescent motivational advice provides protection for students in Indonesia to participate in discussions about children related to challenges or assistance that can be given to adolescents so as not to offend again.
\end{abstract}

\section{Introduction}

A survey in the United States showed that approximately two million minors have carried out crimes, equating to 1 in 8 off all crimes, reflecting the level of violence committed by teenagers. ${ }^{1}$ The children and adolescents who continue along this path tend to become offender as adults. Research with various participants ranging from women, mixed African-Americans, and Native Americans stated that all adolescents at high risk of violence are those who have a history of neglect. ${ }^{2}$ Violence against children in Indonesia also continues to increase every year. It was recorded that in 2011 there were 216 cases which almost doubled in 2012 to 412 cases. KPAI in 2016 noted that in 2014 there were 656 cases of violence against children, either as victims or victims of crime, the highest proportion of cases $(66.69 \%)$ occurred in the school environment compared to at home and communities. ${ }^{3}$

Perpetrators of physical violence found in the age group 13-17 were both male and female with a percentage of $73,11 \%$ female and 74, 37\% male who were committed crimes while they were still at school. ${ }^{4}$ UNICEF 2015 found that in Indonesia there had been widespread violence against children, forty percent of children who reported being attacked or bullied at school were aged 13-15 years and 50\% overall reported being bullied at school. Baglivio and Epps found that among child perpetrators of violence are children who have themselves experienced physical violence and unpleasant treatment. ${ }^{5}$ This may cause them to normalize the idea that violent behavior is a natural characteristic and to become accustomed to it. The results also showed that $45 \%$ to $90 \%$ of teenage violence perpetrators had witnessed violence and experienced trauma due to violent event. ${ }^{6}$ The problem of adolescents becoming perpetrators of violence requires maximum attention and guidance from all parties. It is not impossible that in the future adversity and obstacles to child development will cause more complicated problems. There are concrete steps that must be taken to reduce cases of violence against children, such as health promotion, stress management training for parents and support from the Jakarta Regional Government so that children's rights are protected. Children are unique individuals who have their own way of developing. The existence of an exploration gap between the children and their developmental stages could be a sign that the child has may steer to dangerous conduct. ${ }^{7}$ Children who fail to fulfill their developmental tasks tend to be submissive when facing obstacles in adulthood, they may choose practical paths to obtain certain conveniences and pleasures, and often impose their wills and try to achieve their purposes by any mean. Constitution number 23 from 2002 regarding child protection explains that children are the next generation who are the successors of the nation's ideals who have a strategic role and have the potential to ensure the sustainability of the existence of the nation and state in the future. Data from BPS estimates the number of Indonesian children in 2018 was $33 \%$ of the total population estimate $(88,312,971$ for ages $0-18$ years), of these $59 \%$ were male. The potential for the young generation in Indonesia in the future is great, and the number of cases of violence involving children and adolescents is danger. Overseas pediatric nurses have long played a role in handling violence in children. In a study conducted in Sweden, nurses aged 35-62 years served practiced child health care had work experience ranging from 10 to 41 years of pediatric specialization and

Significance for public health

Children are unique individuals who have their own way of developing. The existence of an exploration gap between the children and their developmental stages could be a sign that the child has may steer to dangerous conduct. Children who fail to fulfill their developmental tasks tend to be submissive when facing obstacles in adulthood, they may choose practical paths to obtain certain conveniences and pleasures, and often impose their wills and try to achieve their purposes by any mean. Constitution number 23 from 2002 regarding child protection explains that children are the next generation who are the successors of the nation's ideals who have a strategic role and have the potential to ensure the sustainability of the existence of the nation and state in the future. 
tended to make more intensive visits to families who aware considered vulnerable in fostering violent behavior in children. The results of this study proven to reduce the occurrence of violent behavior in children, both by the child's parents and by the children themselves to their friends at school. ${ }^{8}$ The facts show how important the role of nurses is, among others, because nurses often interact with children and families, both in primary and secondary health services. ${ }^{9}$ Further research is needed to improve the ability of nurses to deal with violent behavior among adolescents.

The approach to identifying and preventing violence in children has been running with a multidisciplinary approach where all professionals contribute to the aim of keeping children away from violent behavior. Nurses are in a strategic position to contribute toward protecting adolescents from violent behavior. Lines, Hutton, and Grant published research describing the experiences of nurses in child abuse, but this research needs to be further synthesized to determine at more pivotal role of nurses in dealing with adolescent violence perpetrators. ${ }^{10}$ Therefore, researchers felt it was important to choose a topic related to the motivation of child abuse offenders.

\section{Design and Methods}

This study used a qualitative research design with a descriptive phenomenology approach. The study was conducted over 5 months (January-May 2020). The sampling used purposive sampling technique on adolescents who were male perpetrator who were undergoing coaching at the Child Development Prison (LPKA) Jakarta. The inclusion criteria for the participants were adolescents aged 12-18 years who are undergoing coaching due to their violent behavior, were able to speak Indonesian well, and were willing to participate in research. The recruitment process began by selecting the names of potential participants through the LPKA coach (key person) who dealt directly with the participants on a daily basis. The key person in this study was the student guidance staff at Child Special Development Institution Jakarta. The number of samples taken in this study was at least 3-10 participants. A sample of 10 participants could be reduced if there was a realization when conducting interviews that data saturation had been met.

The research instrument was the researcher himself with the required tools: new interviews, field notes and a recording device. The data was collected by means of semi-structured interviews and observations were documented by making field notes. At the time of the interview, the researcher used a recording device that had been previously agreed by the participants. The researcher explained that during the interview the participants would be consistently summoned using the code P1, P2 and so on. The interview that was applied was a semi-structured interview with open questions. This semi-structured interview provides greater freedom and flexibility in answering questions.

Interviews with each participant were planned to last 40-60 min to gather data about the experiences of youth perpetrators of violence who underwent coaching. The interview was concluded after the researcher got a complete picture of the participants' experiences in accordance with the research objectives. The results of the interviews were clarified again to the participants at the second meeting to verify and maintain the credibility of the data. Based on the Pender Theory, the researcher asked several questions during a new interview, which were based on interviews that had already been compiled. The non-verbal responses of the participants and the interview situation were also documented in field notes. Data analysis used a template analysis model and the Colaizzi method. The validity and reliability of the results of this study are based on credibility, transferability, dependability, and confirmability.

Participants in this study are a vulnerable group who need extra protection because they fall into the age group of children. The researcher explained at the beginning of the interview that participant volunteering was needed because this research was conducted under a social institution. Researchers also maintain selfsafety by observing the nature of participants who have a history of violent behavior by asking the LPKA for help to facilitate access to help when an unwanted situation occurs.

\section{Review ethics}

Before conducting research, the researcher must submit a research proposal to the ethical review board of the Faculty of Nursing, University of Indonesia. After going through two revisions in March 2020, the ethical review board of the Faculty of Nursing decided that this research was approved and worthy of research.

\section{Results}

The demographic of the participants showed that they were between 14 and 16 years of age. The length of detention varied from 1-5 years. All participants were male. The characteristics described in detail in Table 1 . The themes found were i) unsafe environmental conditions; ii) unpleasant past events; iii) childhood trauma; and iv) solidarity with peers or associations. A literature review is in line with the results of this research on adolescents, it is revealed that the factors that make adolescents engage in violent behavior are witnessing crime or violence in their environment (an unsafe environment), having experienced abuse or neglect in the family (unpleasant past events). (as well as opportunities to engage in acts of violence in life (solidarity between peers or associations).

\section{Theme 1. Unsafe environmental conditions}

This theme reveals that participants internalize the direct influence of their environmental situation and this can create an urge to become perpetrators of violence. Participants also felt a lack of protection from security forces in their environment which emboldened them to indirectly engage in violent behavior. This information was conveyed by the participants in the following statements:

"This place is a densely populated settlement, Ma'am" (P1) (P3) (P8) (P11).

"How many times did this happen ... so inter-village quarrels often occurs in this area" (P2).

"The name is the new market area, ma'am. That place is a densely populated settlement and the activity there is selling clothes" (P5) (P6).

"The average occupation of the residents around there is labor, laborers from out of town or overseas ... but it's noisy so they can't take a break during the day" (P7).

"The area of Bangka Raya, Mampang, South Jakarta is prone to clashes, Ma'am" (P9).

\section{Theme 2. Unpleasant past event}

This theme illustrates that before entering LPKA and being involved in various acts of violence, they experienced a dark period in their lives, both with in their families and at school. The exis- 
tence of unpleasant experiences that leave a mark in the hearts and minds of children and are unforgettable during their lifetime can be a motivation for adolescents to themselves become perpetrators of violence. This information was conveyed by participants in the following statement:

"My friend was splashed with sulfuric acid by a group of motorcycle gangs some time ago, Ma'am” (P1).

"My school was almost burned down during a brawl in the second grade of Junior High School" (P1).

"I was abandoned by my mother when I was 9 years old and at 16 years old by my father" (P2).

"I want to go back to school but I can't work to pay for my school fees" (P2).

"Even though I didn't go to school, I worked as dishwater at a Pecel Lele Stall" (P2).

"Mother died since 2012 and father 2017" (P2)

"I felt sad and stressed at that time" (P3).

"The incident took place during the New Year so the children did not go to school" (P3).

"An old grudge that had not been erased so when I saw a person being stabbed my emotions immediately ignited" (P3).

"My friend Yoga's revenge when invited to a fight" (P4).

"Schooling is too costly, all my brothers and sisters dropped out of school" (P7).

"I was still in school when I was arrested. I was closer to the home economic teacher than my friends" (P7)

"At that time there was a mass brawl that involved violence, at that time I was only 15 years old ... I was scared because I worked singing and selling on buses" (P10).

"Riders on five motorbikes, assaulted the victim who was walking” (P13).

\section{Theme 3. Childhood trauma}

Trauma is an event that occurs psychologically and causes mental injury to adolescents who experience it. The trauma resulting from a brief event but with a direct impact on the participant will always be remembered by the participant. The participant has been exposed to behavior that makes him psychologically injured, which foments the desire to repeat it in a different situation. This information was conveyed by participants in the following statements:

"He was given a drink mixed with medicine when he was in the third grade of junior high school so that the client became more reckless and courageous" (P1).

"Been bullied" said a pupil while still in school" (P1).

"My brother went to Cipinang prison for murder" (P3).

"Smoking from grade three up to now because it gives the impression that they can earn their own money" (P4).

"Once someone gave me drugs but I remember my mother's message was not to do drugs" (P4)

"In Jelambar, I was beaten by a friend but as long as I didn't get too hot" (P4).

"I stutter, Ma'am ... I was once said to be stuttering at school" (P6).

"Many people say that I only went to elementary and junior high school ... I can only pray that the people who speak ill of me will one day get sick" (P6).

"There were friends who tarnished my parents to the point where I got pissed off, friends, and other people asked me to fight four times with different people until both my eyes were swollen" (P6).

"I had a brawl during the holy month of Ramadan when I was in the second grade of Junior High School. I had wounds on my body that made me hold a grudge against the perpetrator. If I see someone who makes a mistake, I want to fight it out" (P8).

"Every day playing with the children in the park and chatting with those whom are not in school" (P10).

"Trading in candy and nuts from 8-5 in the afternoon with an average net income of 80 thousand at the terminal" (P11).

"When I was six years old, my father was imprisoned inCipinang until 2022 for murder" (P11).

"Since I was little, I didn't know where my mother went and my father never showed me her photos" (P12).

"According to my father, I was difficult to bring up" (P12).

\section{Theme 4. Solidarity with peers or associate}

Most of the participant aware teenagers who came from broken families and lacked proper parental care, an unable environmental situation. These factors encourage adolescents to seek communities where they have the same interests and goals even though they are not aware that their behavior has a negative impact on others.

"At first, I was invited by a friend but refused, but when I saw my friend stabbed, I got into a fight, (P13).

"Invited by a playmate who was caught at that time" P4).

"Before I came, there had been a fight, so I joined (invited by Yoga Sultana) instigated by my friend from childhood" (P4).

Table 1. The characteristic of participants $(n=13)$.

\begin{tabular}{|c|c|c|c|c|}
\hline No. & Age (year) & Education & Care giver & Criminal case \\
\hline 1 & 18 & Elementary & Father & Persecution \\
\hline 2 & 16 & Junior high school & Parents & Beatings \\
\hline 3 & 16 & Elementary & Parents & Beatings \\
\hline 4 & 18 & Elementary & Father & Beatings \\
\hline 5 & 17 & Junior high school & Mother & Persecution \\
\hline 6 & 17 & Elementary & Parents & Brawl \\
\hline 7 & 16 & Junior high Scholl & Parents & Brawl \\
\hline 8 & 15 & Elementary & Aunty & Brawl \\
\hline 9 & 18 & Senior high school & Parents & Brawl \\
\hline 10 & 18 & Junior high school & Beggar & Violent theft \\
\hline 11 & 18 & Elementary & Brother & Violent theft \\
\hline 12 & 18 & Elementary & Father & Violent theft \\
\hline 13 & 16 & Elementary & Parent & Violent theft \\
\hline
\end{tabular}


"Attacked first while playing football, there was a motorcycle gang” (P5).

"Friends with guns, I just followed suit" (P5).

"When I was relaxing, I was invited by a friend to fight, that was the first fight then I was given a weapon in the form of a sickle, before I had never used a sickle" (P6).

"There are gangs and have been invited to play there but the mother forbids them because they often create problems such as quarrels between residents" (P7).

"First of all, they gathered together then looked for children who had returned from school and were then attacked" (P7).

"Never, through DM Ig Pejaten Pasar Minggu” (P8).

"My friend asked me, in the morning in the market area, when the victim got off the bus, my friend looked immediately then followed from behind and immediately took his cellphone, carrying a sharp weapon" (P10).

"Many friends who helped to do it, the place was attacked by a crowd even though they couldn't do martial arts" (P10)

"The five perpetrators were friends in the Plumpang's bridge" (P11).

"Associate, invited by an older friend, advised me to carry a sharp weapon" (P11).

"Only invited by friends who are older and knew the street, friends hanging out in Gading, North Jakarta, who attacked five people" (P12).

"It was planned but I did not to carry a sharp weapon, at that time I was in a brave mood" (P13).

\section{Discussion}

Child growth is strongly influenced by environmental factors that determine adolescent behavior and character. A teenager who lives and develops in a bad environment will develop moral characteristic that reflect his environment. ${ }^{11}$ The theory of the influence of social life on the formation of personal identity is also discussed in other literature. ${ }^{12}$ Social life also shapes individual personalities as a response to social stimuli which will have an impact on whether or not the character formation of the younger generation is good. ${ }^{12}$ The theory of children's personality development is influenced by several elements that surround children's live. ${ }^{13}$ The factors that influence children's lives are family, neighbors, peergroups, communities, countries, and the world in which they live and grow. Adolescents often cause disturbances because they often witness violent behavior in their environment, such as brawls. When there is a brawl or violent behavior in the community, there are no officers or moral control of the community to stop the acts of violence so that adolescents consider this to be the norm. External motivation from the environment is what ultimately channel adolescents to become perpetrators of violence.

Adolescents who experience physical or mental abuse, harassment or bullying and are neglected with in the social and family environment, show significantly violent behavior which causes them to have to interact with the authorities. ${ }^{7}$ Adolescents in this study experienced problems within the family, environmental rejection and even bullying from people around them. This is supported by research by Wulandari and Nurwati who concluded that the emotional formation of adolescents in the past can lead to longterm social problems. ${ }^{14}$ Albert Bandura, who is well-known in social cognitive learning theory, ${ }^{12,15}$ revealed that adolescents learn to imitate the behavior they observe from others. External forces and environmental influences are not the only factors influencing individual learning and behavior. Individual mental condi- tion still plays a pivotal role in shaping the behavior and learning process that he experiences. This social cognitive theory emphasizes that in addition to social factors, individual cognitive and mental factors play an important role in learning.

Previous studies have revealed that trauma in childhood could influence a person to become a violent teenager. ${ }^{13}$ In this study, trauma in adolescents was measured using a special screening (Youth Screening Instrument, ver. 2) where a correlation was found between violent behavior with childhood trauma. As a result of this trauma will form inner wounds that are stored and have the potential to undermine one's mental attitude making it difficult to do positive thing. The effect on the lives of adolescents is that their future lives will always recall traumatic experiences and deep sadness. Children who experience trauma even though the incident was not directly experienced (seen and heard), sometimes follow commands from their subconscious brain to reproduce the incident. Research on the influence of peers on adolescent behavior or their decision to take an action has been studies. ${ }^{16}$ That study found a correlation between interactions among adolescents and how they socialize. Other studies state that this correlation is also influenced by environmental and cultural factors. Peer groups for adolescents play an important role for their personality development. ${ }^{6}$ Development of self-identity and interpersonal communication skills is influenced by the association with obtained from peers. Pei stated in research that the motivation of adolescents to decide to take risky actions or adjust a behavior can be due to peer influence.${ }^{17}$ Factors from outside adolescents that could affect their ability to deal with stress are called peer group support or what is commonly called peer group assistance. Teens tend to trust to their peers more and reveal their problems because they often feel high level of empathy, sympathy, tolerance and solidarity. Even to avoid conflict with peers, adolescents choose to follow both positive and negative ways to solve the problems they face. ${ }^{18}$ Adolescents who are not accepted and have poor quality relationships with children their age tend to use maladaptive behavior as a strategy when they interact. So that children who gravitate towards violence will choose to join peers who approve or even behave the same as them. This will aggravate their behavior so that it has a negative impact on both themselves and others. ${ }^{19}$

This research also explores the types of motivation that shape a teenager to engage in ever escalating violent conduct until he has to deal with the law. The Nola J. Pender health promotion model is a theoretical framework influenced by Albert Bandura's social learning theory, regarding the importance of various cognitive processes in behavior change. ${ }^{20}$ The theme formed from the research results is related to the theory of Nola J. Pender health promotion model, such as the factors that shape violent behavior in adolescent. This is experience of either witnessing or directly imitating violent behavior either once or several times so that it will remain in the subconscious of adolescents in the future. They then often repeat the behavior regardless of the negative impact on others. The influence of external factors on adolescents to become perpetrators of violence originate from their social environment and peers. These two factors make teenagers dare to take high risks when they do something and even act against the law. The combination of external and internal aspects found in this research theme systematically shapes adolescents to become perpetrators of violence.

\section{Conclusions}

This study involved 13 adolescent participants who had a history of violent behavior. The age range of participants was between 
14-18 years old with education levels from elementary school, junior high school and senior high school. All participants were male. The study identified themes that describe the motivation of adolescents to become perpetrators of violence, namely i) an unsafe environment; ii) unpleasant past events; iii) childhood trauma; and iv) peer solidarity or relationships.

\section{Research limitations}

During the data collection process, several cases were found, during the participant interview process, there were changes to the data collection method, namely direct interviews and via videocall (after the COVID-19 outbreak) so that there were slight differences in the participants' expressions and body language.

Correspondence: Nani Nurhaeni, Department of Pediatric Nursing, Faculty of Nursing, Universitas Indonesia, Jalan Prof. Dr. Bahder Djohan, UI Depok Campus, Depok, West Java 16424, Indonesia. Tel. +62.21.78849120 - Fax: +62.21.7864124

E-mail: nani-n@ui.ac.id

Key words: Motivation; boy adolescents; perpetrators.

Contributions: All authors contributed equally. NN, AL supervised conceptualization and design the study, revising it critically for important intellectual content, final approval. MZ, concept and design analysis and interpretation of data, drafting manuscript.

Conflict of interest: The authors declare no conflict of interest, financial or otherwise.

Acknowledgments: The authors would thank all respondents and all parties who had helped the completion of this research. Our deepest gratitude was also expressed to the Direktorat Riset dan Pengembangan Universitas Indonesia for funding this research with fund PUTI Saintekes 2020 Number: NKB-4613/UN2.RST /HKP.05.00/2020.

Institutions where the research was carried out: Special Child Development Institution (LPKA) Class II Jakarta Human Resources Development Agency (BPSDM) Law and Human Rights Jalan Raya Gandul, Kelurahan Gandul, Kecamatan Cinere, Depok City, West Java 16512 http://lpkajakarta.kemenkumham.go.id

Ethics approval and consent to participate: This study has been approved by Ethics Committee of Faculty of Nursing Universitas Indonesia, Depok with Number: SK-19/UN.2.F12.D1.2.1/ ETIK.FIK.2020. For respondent who participated in the research, fill out the informed consent form.

Availability of data and materials: The datasets analyzed in this study are available from the corresponding author on reasonable request.

Conference presentation: This final manuscript has been presented at $7^{\text {th }}$ Virtual Biennial International Nursing Conference, Faculty of Nursing, Universitas Indonesia on September $24^{\text {th }}$, October $30^{\text {th }}$, November $16^{\text {th }} 2020$.

Received for publication: 14 August 2020

Accepted for publication: 23 April 2021.

${ }^{\circ}$ Copyright: the Author(s), 2021

Licensee PAGEPress, Italy

Journal of Public Health Research 2021; 10(s1):2407

doi:10.4081/jphr.2021.2407

This work is licensed under a Creative Commons Attribution NonCommercial 4.0 License (CC BY-NC 4.0).
Researchers when interviewing participants who first asked for permission through an informed consent signed by a student caregiver, in this case a nurse who had previously interviewed male adolescents who were given orally about the research objectives, was because the protocol was quite strict so that participants had to be asked first from in custody by duty officers so that participants do not want to follow LPKA procedures before they can meet and can provide explanations from researchers directly.

\section{References}

1. Fox BH, Perez N, Cass E, et al. Trauma changes everything: examining the relationship between adverse childhood experiences and serious, violent and chronic juvenile offenders. Child Abuse Negl 2015;46:163-73.

2. Ryan J, William AB, Courtney ME. Adolescent neglect, juvenile delinquency and the risk of recidivism. J Youth Adolesc 2013;42:454-65. d

3. Melontige SKA. [Psikoedukasi kesehatan reproduksi sebagai perlindungan diri dari kekerasan seksual pada anak 5-6 tahun (Reproductive health psychoeducation as self-protection from sexual violence against children 5-6 years)].[Thesis in Indonesian]. Depok: Universitas Indonesia; 2016.

4. Kurniasari A, Wismaayanti FY, Irmayani, et al. [Ringkasan hasil: survey kekerasan terhadap anak Indonesia tahun 2013 (Summary of results: 2013 survey of violence against children in Indonesia)].[in Indonesian]. Jakarta: Ministry of Women's Empowerment and Child Protection of the Republic of Indonesia; 2013. Available from: https://www.kemenpppa. go.id/lib/uploads/list/0e33f-skta-2013.pdf

5. Baglivio MT, Epps N. The interrelatedness of adverse childhood experiences among high-risk juvenile offenders. Youth Violence Juv Justice 2015;14:179-98.

6. Septiyuni DA, Budimansyah D, Wilodati W. [Pengaruh kelompok teman sebaya (peer group) terhadap perilaku bullying siswa di sekolah (The influence of peer groups on student bullying behavior at school)].[Article in Indonesian]. SOSIETAS 2015;5.

7. Susantyo B. [Lingkungan dan perilaku agresif individu (Environment and individual aggressive behavior)].[Article in Indonesian]. Sosio Informa 2017;3:15-25.

8. Dahlbo M, Jakobsson L, Lundqvist P. Keeping the child in focus while supporting the family: Swedish child healthcare nurses experiences of encountering families where child maltreatment is present or suspected. J Child Health Care 2017;21:103-11.

9. Caneira L, Myrick KM. Diagnosing child abuse: the role of the nurse practitioner. J Nurse Pract 2015;11:640-6.

10. Lines LE, Hutton AE, Grant J. Integrative review: nurses' roles and experiences in keeping children safe. J Adv Nurs 2017;73:302-22.

11. Stimmel MA, Cruise KR, Ford JD, Weiss RA. Trauma exposure, posttraumatic stress disorder symptomatology, and aggression in male juvenile offenders. Psychol Trauma 2014;6:184-91.

12. Ainiyah Q. S[ocial learning theory dan perilaku agresif anak dalam keluarga (Social learning theory and aggressive behavior of children in the family)].[Article in Indonesian]. AlAhkam Jurnal Ilmu Syari'ah dan Hukum 2017;2:91-104.

13. Farina ASJ, Holzer KJ, DeLisi M, Vaughn MG. Childhood trauma and psychopathic features among juvenile offenders. Int J Offender Ther Comp Criminol 2018;62:4359-80. 
14. Wulandari V, Nurwati N. [Hubungan kekerasan emosional yang dilakukan oleh orangtua terhadap perilaku remaja (The relationship of emotional violence by parents to adolescent behavior)].[in Indonesian]. Research and Community Service Proceedings 2018;5:132-6.

15. Tabachnick J. Do children sexually abuse other children? preventing sexual abuse among children and youth. Northampton, MA: Stop it now!; 2016. Available from: https://www.stopitnow.org/sites/default/files/documents/files/do_children_sexually_abuse_other_children_0.pdf

16. Wolff K, Baglivio MT, Piquero AR. The relationship between adverse childhood experiences and recidivism in a sample of juvenile offenders in community-based treatment. Int $\mathrm{J}$ Offender Ther Comp Criminol 2017;61:1210-42.

17. Pei R, Lauharatanahirun N, Cascio $\mathrm{CN}$, et al. Neural processes during adolescent risky decision making are associated with conformity to peer influence. Dev Cogn Neurosci 2020;44:100794.

18. Astuti YW, Dewi NK, Sumarwoto VD. [Pengaruh peer group support dan resillience terhadap kemampuan coping adaptif siswa SMA (The effect of peer group support and resillience on the adaptive coping ability of high school students)].[Article in Indonesian]. Counsellia: Jurnal Bimbingan dan Konseling 2018;8:27-36.

19. Sumara D, Humaedi S, Santoso MB. [Kenakalan remaja dan penanganannya (Juvenile delinquency and its handling)].[in Indonesian]. Research and Community Service Proceedings 2017;4:346-53.

20. Alligood MR. Nursing theory: utilization \& application. St. Louis: Mosby Elsevier; 2014. 